\title{
Genetic Selection for High and Low Fasting Blood Glucose Levels in Mice. I. Fasting Blood Glucose Levels, Glucose Tolerance and Isolated Tissue Studies*
}

\author{
R.E. Gleason, P.L. Poffenbarger, and R. L. Lavine \\ Elliott P. Joslin Research Laboratory, Department of Medicine; Harvard Medical School and Peter Bent Brigham \\ Hospital; Joslin Diabetes Foundation, Inc., and New England Deaconess Hospital, Boston, Massachusetts, U.S.A.
}

Received: September 11, 1972, and in revised form; March 4, 1973, accepted: March 9, 1973

Summary. Swiss-Hauschka mice have been selected for high (HG) and low (LG) fasting blood glucose (FBG) levels for four generations. All matings were brother to sister. Differences in mean FBG levels have remained relatively constant ( 20 to $30 \mathrm{mg} \%$ ) between the two lines since initiation of selection $(p<0.001)$. Body weights have declined more rapidly with inbreeding in the LG line as compared to the $\mathrm{HG}$ line through $\mathrm{F}_{3}$, but no further decline was noted in the $\mathrm{F}_{4}$ generation. Fasting serum immunoreactive insulin (IRI) levels were variable and mean levels for the two lines did not differ significantly. A comparison of glucose tolerance data between $\mathrm{F}_{3} \mathrm{HG}$ and LG line animals showed generally higher mean glucose levels in the $\mathrm{HG}$ line in both fasted and randomfed states.
The mean delta glucose levels during the test, however, were nearly identical in both lines. A dietary influence on glucose tolerance was shown. Several in vitro tissue studies revealed no significant differences in hepatic glycogen and pancreatic insulin content between $H G$ and $L G$ line animals. Isolated tissue sensitivity to insulin appeared indistinguishable between the lines; however, hepatic glu. coneogenesis and retinal glucose $-6-{ }^{14} \mathrm{C}$ oxidation rates in HG line mice may be enhanced.

Key words: Mice, genetic selection, fasting blood glucose, body weight, ghucose tolerance, insulin, dietary fat, isolated tissues, randomfed.
The study of diabetes in experimental animals and the use of laboratory animals as experimental models for diabetes in humans has recently been enhanced by the discovery of several species showing spontaneous development of the disease [1]. Sufficient information has been obtained from these studies, as well as from human studies, to indicate that the development of diabetes is influenced by both heredity and environment.

In previously reported studies from this laboratory $[2,3]$, it was noted that mean random blood glucose levels were elevated in randombred Swiss Hauschka mice maintained on a commercial $11 \%$ fat diet. ${ }^{1}$ Some animals in this study, however, remained normoglycemic, thus suggesting a possible hereditary influence on blood glucose concentration.

Early studies by Cammidge and Howard $[4,5]$ indicated that hyperglycemia and hypoglycemia in mice were inherited as separate characters, both recessive to normoglycemia. Hypoglycemia was also reported to be recessive to hyperglycemia. Segregation in all cases appeared to be absolute, with no intermediate values reported. These data were subsequently discussed by Dunn and Fisher [6] and by Gruneberg and Haldane [7]. In both of these papers, the authors commented on the remarkable agreement of Cammidge and Howard's observed data with that expected on the basis of simple Mendelian inheritance.

* Supported in part by U.S.P.H.S. Grants AM-11959, AM-09748, 1-FO3-AM-30777, and AM-05077, and the Upjohn Company, Kalamazoo, Michigan.

1 Old Guilford Breeder Pellets, Fmory Morse Company, Guilford, Connecticut.
The apparent segregation of mice on the $11 \%$ fat diet into normo- and hyperglycemic groups, along with the uncorroborated blood glucose inheritance data of Cammidge and Howard led to the initiation of genetic selection on the basis of blood glucose levels to develop high and low blood glucose lines. This paper presents the results of selection through the $\mathrm{F}_{4}$ generation with respect to blood glucose and serum immunoreactive insulin levels, and body weights. In addition, glucose tolerance tests and several types of metabolic studies on isolated tissues were performed on groups of $\mathbf{F}_{3}$ animals to determine if line differences could be detected.

\section{Material and Methods}

\section{Genetic Selection}

Fifty male and fifty female weanling randombred Swiss Hauschka mice were obtained from a commercial source. ${ }^{2}$ Males and females were maintained separately, six to ten animals per cage, and all animals received water and the $11 \%$ fat commercial diet ad libitum. Body weights were recorded bimonthly. Fasting blood glucose (FBG) levels were measured at 6.5 and 8 months of age following an overnight fast. Five males with FBG levels greater than $80 \mathrm{mg} \%$ and eight females with levels greater than $75 \mathrm{mg} \%$ were selected as parents for a high glucose (HG) line. An additional four males with FBG levels less than $60 \mathrm{mg} \%$ and eight females with

2 Charles River Breeding Laboratories, Wilmington, Massachusetts. 
levels less than $57 \mathrm{mg} \%$ were selected as parents for a low glucose (LG) line. These 25 mice included approximately $10 \%$ of the males and $20 \%$ of the females from each end of the distribution. Following a third FBG measurement at 8.5 months of age, three male and three female $H G$ animals and an equal number of $L G$ animals were selected from the group of 25 and mated. These six matings constituted the $\mathbf{P}_{1}$ generation.

Selection of parents for subsequent generations was based on three FBG levels measured between 4.5 and 6 months of age. In general, blood samples were taken at $5,5.5$, and 6 months. The criteria for selection were three relatively constant FBG levels characteristic of the parental line; that is, either high or low. At six months of age blood samples for serum immunoreactive insulin (IRI) were obtained.

All matings (brother to sister) were made at six months of age and these selected animals changed to a $4 \%$ fat commercial diet. ${ }^{3}$ The dietary change was instituted for two reasons. First, the low fat diet generally caused animals which were hyperglycemic on the $11 \%$ fat diet to become normoglycemic. Second, after several months on the $11 \%$ fat diet most of the animals became obese, and changing to the low fat diet decreased the caloric intake, lowered the body weight, and resulted in better breeding performance. Offspring were weaned at three weeks of age and placed on the $11 \%$ fat diet. Body weights were recorded monthly.

All blood samples were obtained from the tail after an overnight fast. Samples for glucose measurement consisted of $0.05 \mathrm{ml}$ of blood rapidly transferred into a cup containing $0.95 \mathrm{ml}$ of distilled water and frozen for subsequent analysis by the AutoAnalyzer ${ }^{4}$ using Technicon Method N-9a.

For serum IRI levels, an additional $0.2 \mathrm{ml}$ of tail blood was collected directly into a small polyethylene tube, allowed to clot overnight at $4^{\circ} \mathrm{C}$, then centrifuged, and the serum separated and frozen until assay. Serum IRI levels were determined by a modification of the double antibody method [8] wherein $0.05 \mathrm{ml}$ of serum was used, and the length of the second incubation period was increased to five days. A purified mouse insulin standard with biological and immunochemical potency of $25 \mathrm{U} / \mathrm{mg}$ was used [9].

\section{Glucose Tolerance}

A total of 30 glucose tolerance tests were completed in $21 \mathrm{HG}$ and $L G$ line $\mathbf{F}_{3}$ mice. Two groups of animals were studied. Group I consisted of four HG and five LG line males of similar body weights and ranging in age from 6.5 to 9 months. A second group (Group II), consisted of four $\mathrm{HG}$ and four LG line males on the $4 \%$ fat diet, and four LG males on the $11 \%$ fat diet. These animals ranged in age from 10 to 12.5 months, and the

3 Purina Laboratory Chow, Ralston Purina Company, St. Louis, Missouri.

4 Technicon Instruments Corporation, Chauncey, New York. mean body weights for the three subgroups were similar.

Each animal in Group I had two glucose tolerance tests, one after an overnight fast, and the second one week later in the randomfed state. Group II animals had a single glucose tolerance test in the fed state. Blood samples were obtained from the tail at time 0 , and at $0.5,1$, and $2 \mathrm{~h}$ after administration of glucose (1 $\mathrm{mg} / \mathrm{gm}$ body weight of $20 \%$ glucose solution, intraperitoneally). Glucose levels were measured by an ultra-micro glucose oxidase method utilizing $5 \mu \mathrm{l}$ of blood [10].

\section{Isolated Tissue Studies}

Eight $\mathrm{HG}$ and LG males approximately 1 year old were used. The animals were sacrified by decapitation after a $14 \mathrm{~h}$ fast; blood was allowed to clot at $4^{\circ} \mathrm{C}$ for $6 \mathrm{~h}$ and the serum from each line was frozen. Nonsuppressible and suppressible insulin-like activity (NSILA, SILA) were determined on each serum pool by a modification of the bioassay method of Renold (11) using purified mouse insulin as standard. This modification entailed the division of the peripheral aspect of the mouse fat pad into $10-12$ segments, each weighing $15-20 \mathrm{mg}$; these segments were then randomly distributed into each incubation flask. Mouse epididymal fat sensitivity to mouse insulin was studied in an identical fashion to the bioassay procedure. Hemidiaphragm incubations were performed as outlined by Ensinck et al. [12].

Retinae were isolated in chilled Krebs-Ringer bicarbonate buffer with the aid of a dissecting lamp; 2 retinae were incubated for $2 \mathrm{~h}$ in $2 \mathrm{ml}$ buffer containing $280 \mathrm{mg} / 100 \mathrm{ml}$ glucose plus $0.2 \mu \mathrm{c}^{14} \mathrm{C}$-glucose. ${ }^{5}$ Dry weights were obtained following incubation on preweighed evaporating discs. Glucose concentration in the medium was determined as described above using the ultramicro modified glucose oxidase method and ${ }^{14} \mathrm{CO}_{2}$ trapped and counted as in the bioassay protocol. Values are presented as umoles of specifically labeled carbon from glucose recovered as ${ }^{14} \mathrm{CO}_{2}$ and as moles of non-labeled glucose disappearing from the medium, both per milligram of dry tissue per hour of incubation.

Hepatic gluconeogenesis was studied as described by Krebs, Notton and Hems [13] using $10 \mathrm{mM}$ lactic acid as substrate. Hepatic glycogen content was determined before and after incubation by the method of Van Handel [14]. Pancreatic insulin was extracted from pooled pancreata by the method of Davoren [9] and quantitated by the modified rat fat pad segment bioassay [11]. Protein concentration was analyzed by the colorimetric method of Lowry [15] using porcine insulin as standard.

Between and within line comparisons of mean data were made using paired and unpaired t-tests. Pearson's

5 New England Nuclear, Boston, Massachusetts. 
Correlations were used to determine the relationship between FBG, fasting IRI and body weight [16].

\section{Results}

\section{Genetic Selection}

Mean and standard deviations for FBG levels and body weights for 47 male and 50 female randombred Swiss Hauschka mice at 6.5 months of age were $69 \pm 11$ and $63 \pm 10 \mathrm{mg} \%, 43.1 \pm 5.7$ and $43.1 \pm 10.6 \mathrm{~g}$, respectively. FBG levels in males were higher than in females $(p<0.01)$, and were significantly correlated with body weight $(p<0.001)$. In females, however, FBG and body weight were not significantly correlated. shown a gradual decrease during the first three generations of selection and inbreeding, with little or no further decline in the $\mathbf{F}_{\mathbf{4}}$ generation.

Mean fasting serum IRI levels (Tab. 1), measured at 6 months of age were much more variable than the corresponding FBG levels, and did not differ significantly between lines. A gradual decline in mean serum IRI levels, similar to that seen in FBG, was also noted during the first three generations of selection. Due to technical problems, the fasting IRI data obtained from the $\mathrm{F}_{4}$ animals were not usable.

Comparison of mean fasted body weights between lines showed significantly higher 6 month weights in $\mathrm{F}_{1}, \mathrm{~F}_{3}$ and $\mathrm{F}_{4} \mathrm{HG}$ males and females ( $p<0.02$ or less). The differences in generation $\mathbf{F}_{2}$ were not significant. Mean randomfed, as well as mean fasting body weights,

Table 1. Mean fasting blood glucoses ( $F B G$ ), immunoreactive insulins (IRI), and body weights ( + standard deviations) in HG and LG-line Swiss Hauschka mice at six months of age following successive generations of selection and inbreeding

\begin{tabular}{|c|c|c|c|c|c|}
\hline Generation & $\mathrm{n}$ & $\mathrm{FBG}(\mathrm{mg} \%)$ & \multicolumn{2}{|c|}{$\operatorname{IRI}(\mu \mathrm{U} / \mathrm{ml})$} & $\begin{array}{l}\text { Body } \\
\text { Weight } \\
\text { (g) }\end{array}$ \\
\hline $\begin{array}{l}\mathbf{H G} \text { line male } \\
\mathbf{F}_{\mathbf{1}} \\
\mathbf{F}_{2} \\
\mathbf{F}_{3} \\
\mathbf{F}_{\mathbf{4}}\end{array}$ & $\begin{array}{r}14 \\
42 \\
93 \\
145\end{array}$ & $\begin{array}{r}108 \pm 20 \\
99 \pm 21 \\
88 \pm 19 \\
85 \pm 19\end{array}$ & $\begin{array}{c}65 \pm 34 \\
41 \pm 32 \\
35 \pm 27 \\
=\end{array}$ & $(10)^{\mathrm{a}}$ & $\begin{array}{l}50.8 \pm 4.6 \\
47.4 \pm 6.8 \\
44.8 \pm 4.7 \\
44.2 \pm 5.9\end{array}$ \\
\hline $\begin{array}{l}\text { LG line male } \\
\mathbf{F}_{1} \\
\mathbf{F}_{2} \\
\mathbf{F}_{3} \\
\mathbf{F}_{4}\end{array}$ & $\begin{array}{r}19 \\
60 \\
118 \\
93\end{array}$ & $\begin{array}{l}73 \pm 16 \\
70 \pm 17 \\
59 \pm 15 \\
49 \pm 9\end{array}$ & $\begin{array}{c}60 \pm 32 \\
40 \pm 33 \\
42 \pm 39 \\
-\end{array}$ & $\begin{array}{l}(13) \\
(54)\end{array}$ & $\begin{array}{l}48.8+5.3 \\
45.6 \div 6.3 \\
39.25 .6 \\
37.2 \pm 4.4\end{array}$ \\
\hline $\begin{array}{l}H G \text { line feme } \\
\mathbf{F}_{1} \\
\mathbf{F}_{2} \\
\mathbf{F}_{3} \\
\mathbf{F}_{4}\end{array}$ & $\begin{array}{r}17 \\
39 \\
100 \\
137\end{array}$ & $\begin{array}{l}87 \pm 15 \\
82 \pm 22 \\
77 \pm 15 \\
75 \pm 14\end{array}$ & $\begin{array}{c}84 \pm 57 \\
45 \pm 49 \\
35 \pm 31 \\
-\end{array}$ & $(10)$ & $\begin{array}{l}53.0 \pm 6.5 \\
43.3 \pm 9.3 \\
40.9 \pm 6.8 \\
42.7 \pm 7.3\end{array}$ \\
\hline $\begin{array}{l}\text { LG line fema } \\
\mathbf{F}_{1} \\
\mathbf{F}_{2} \\
\mathbf{F}_{3} \\
\mathbf{F}_{4}\end{array}$ & $\begin{array}{r}17 \\
55 \\
110 \\
92\end{array}$ & $\begin{array}{l}66 \pm 12 \\
62 \pm 15 \\
54 \pm 13 \\
49 \pm 11\end{array}$ & $\begin{array}{c}83 \pm 38 \\
39 \pm 33 \\
41 \pm 33 \\
-\end{array}$ & $\begin{array}{r}(4) \\
(50) \\
(106)\end{array}$ & $\begin{array}{l}43.4 \pm 6.3 \\
40.2 \pm 7.1 \\
33.5 \pm 5.4 \\
33.0 \pm 5.5\end{array}$ \\
\hline
\end{tabular}

On the basis of three FBG measured at $6.5,8$, and 8.5 months of age, three pairs of HG and three pairs of LG mice were selected and mated. These matings were maintained on the $4 \%$ fat diet.

Of the three $\mathrm{P}_{\mathbf{1}} \mathrm{HG}$ line matings only one produced offspring, whereas two of the three $P_{1} L G$ line matings were fertile.

Mean FBG, IRI, and body weights for generations $\mathrm{F}_{1}$ to $\mathrm{F}_{4}$ are shown in Table 1 for both HG and LG line mice. In general mean FBG levels in HG line males and females have remained about 30 and $20 \mathrm{mg} \%$ higher, respectively, than their LG line counterparts $(p<$ 0.001 ) throughout the four generation selection period. Also males consistently show significantly higher FBG levels than females in both lines. FBG levels have tended to decrease during the selection period in a manner similar to that observed in FBG and IRI levels.

In the $F_{1}$ generation, body weights and FBG at six months of age were not significantly correlated in $\mathrm{HG}$ line males, HG line females, or LG line females, but were $(p<0.025)$ in LG line males, however. Significant correlations ( $p<0.05$ or less) were noted in males and females of both lines in all subsequent generations.

\section{Glucose Tolerance Tests}

Group I consisted of four HG and five LG line males on the $11 \%$ fat diet with similar body weights (means $\pm \mathrm{SD}: 48.5 \pm 5.7$ and $47.8 \pm 5.5 \mathrm{~g}$, respectively), 
ranging in age from 6.5 to 9 months. Each animal received two glucose tolerance tests, one after an overnight fast, and the second one week later in the fed state. The results are shown in Fig. 1. Because of individual variation, mean fasting levels (Fig. 1a) were not significantly different between the two lines. All mice reached peak glucose levels at $30 \mathrm{~min}$, with mean levels and standard deviations of $228 \pm 37$ and $161 \pm$ $40 \mathrm{mg} \%$ for $\mathrm{HG}$ and LG lines, respectively $(p<0.05)$. When the mean changes in glucose were compared in the two lines, it was noted that $H G$ line animals had a significantly greater rise to $30 \mathrm{~min}(p<0.05)$, and a more rapid drop in the second half hour $(p<0.02)$ than the LG line mice. In the randomfed state (Fig. 1 b), the $\mathrm{HG}$ line animals had significantly higher mean glucose levels during the early phase of the test than LG line mice. The mean change in glucose levels however, did not differ significantly between the two lines at any time during the test.

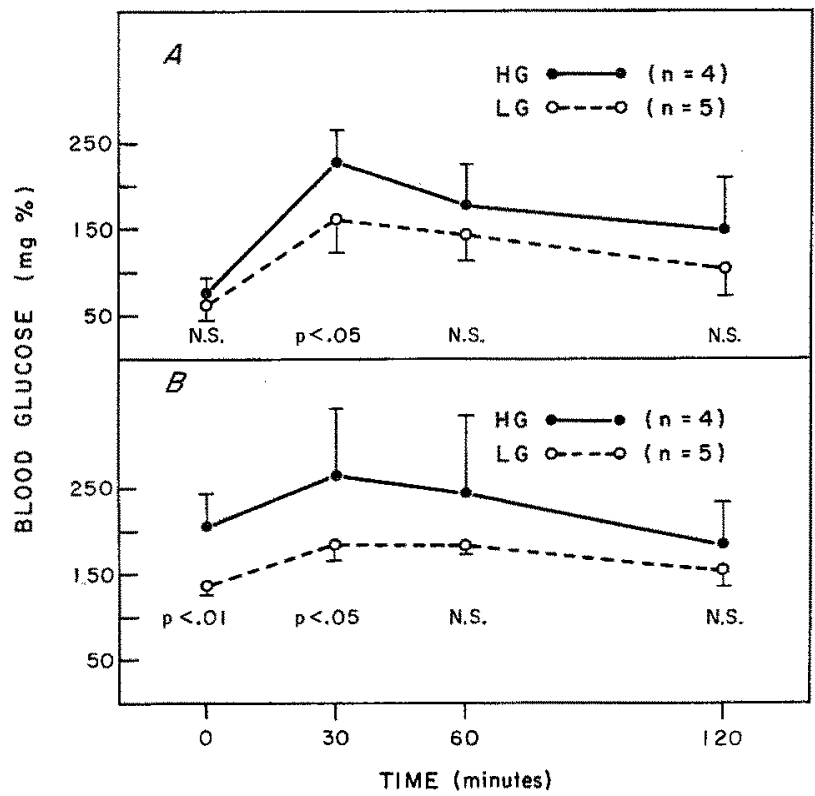

Fig. 1. Glucose tolerance test results in Group I male $\mathrm{HG}$ and LG line mice 6.5 to 9 months of age (mean glucose levels, standard deviations, and significance levels). A. Fasted; B. Randomfed

In order to define the dietary influence on glucose tolerance more precisely, a second group of animals consisting of four $\mathrm{HG}$ and four $\mathrm{LG}$ line males on the $4 \%$ fat diet since six months of age, and four LG males on the $11 \%$ fat diet were studied. These animals ranged in age from 10 to 12.5 months, and their mean body weights were similar (means $\pm \mathrm{SD}: \mathrm{HG} 4 \%$ fat, $48.8 \pm$ $2.8 ; \mathrm{LG} 4 \%$ fat, $47.4 \pm 2.8$; and $\mathrm{LG} 11 \%$ fat, $44.6 \pm$ $5.4 \mathrm{~g})$. Each Group II animal received a single glucose tolerance test in the randomfed state and the results are shown in Fig. 2. Comparison of $\mathrm{HG}$ and $\mathrm{LG}$ animals on the $4 \%$ fat diet (Fig. 2a) showed no significant differences in the mean delta glucose levels between the two lines. Comparison of LG line mice on $4 \%$ and $11 \%$ fat diets (Fig. $2 \mathrm{~b}$ ) showed that mean changes in glucose level were significantly greater for LG line mice on the $11 \%$ fat diet during the second $30 \mathrm{~min}$ of the test $(p<0.01)$. This was due to the fact that all four LG mice on the low fat diet had peak glucose levels at $60 \mathrm{~min}$, whereas all LG mice on the high fat diet reached maximum levels at $30 \mathrm{~min}$ following the glucose load. During the final hour of the test, the LG animals on the $4 \%$ fat diet showed a slightly greater change in glucose than those on the $11 \%$ fat diet $(p<0.1)$. It was noted that the $H G$ males on the $4 \%$ fat diet performed almost identically to LG males fed an $11 \%$ fat diet following a glucose load (Fig. 2c).

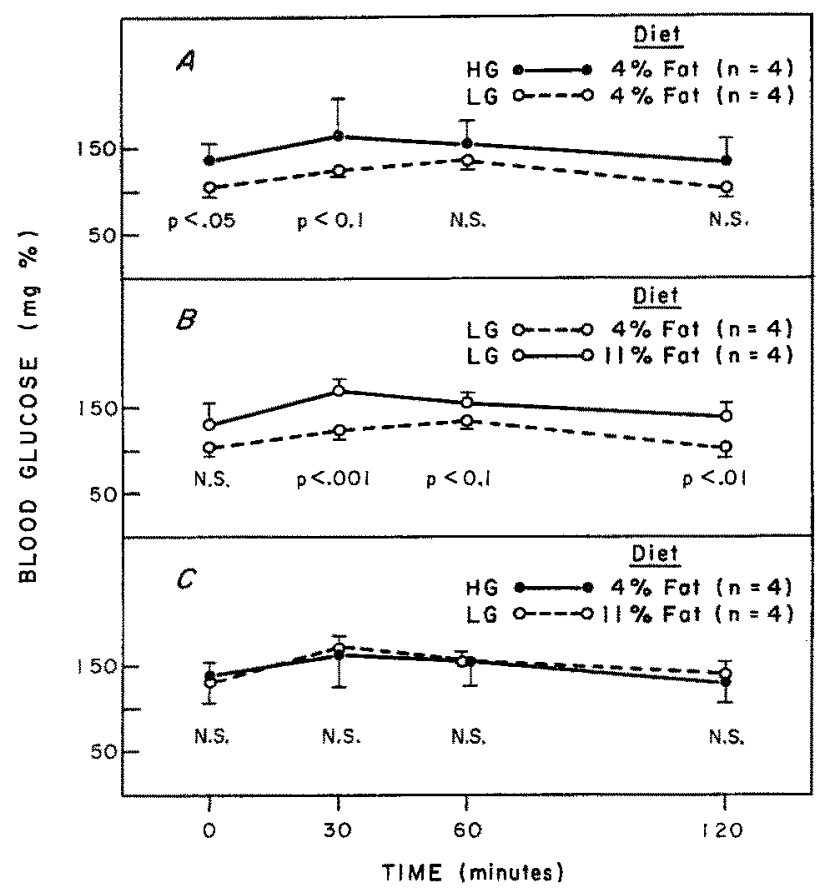

Fig. 2. Influence of diet on glucose tolerance test results in Group II randomfed HG and LG line male mice 10 to 12.5 months of age (mean glucose levels, standard devia. tions, and significance levels)

\section{Isolated Tissue Studies}

Eight male $F_{3}$ mice from each line, ranging in age from 10 to 15 months, were matched for age and weight. These studies were primarily designed to assess potential differences in 1. peripheral tissue sensitivity to mouse insulin, 2. serum insulin like activity, 3. pancreatic insulin content, 4 . hepatic glyeogen content and gluconeogenesis from lactate, and 5 . yields of ${ }^{14} \mathrm{CO}_{2}$ from glucose-1. ${ }^{14} \mathrm{C}$ and glucose-6- ${ }^{14} \mathrm{C}$ metabolism in isolated retinae.

The results of these studies are summarized in Table 2. Both lines showed a significant hemidiaphragm response to mouse insulin $(p<0.001)$, but mean percent increase in glucose uptake over basal (27.4 1 20.5, 
$\mathrm{HG} ; 38.3 \pm 27.8 \mathrm{LG}$ ) did not differ significantly between the two lines. Fat tissue from $H G$ animals exhibited greater glucose oxidation at insulin concentrations of $13 \mu \mathrm{U}(p<0.01)$ and $63 \mu \mathrm{U}(p<0.05)$, but not at the higher concentrations, than LG mice. No differences were found in isolated retinal metabolism, hepatic glycogen, gluconeogenesis, or pancreatic insulin between the two lines.
This paper summarizes the results of the first four generations of selection and inbreeding of Swiss Hauschka mice on the basis of FBG only. It is of interest that the difference in FBG between the lines has remained almost constant from $\mathrm{F}_{1}$ through $\mathrm{F}_{4}$. This fact would tend to support the single autosomal gene mode of inheritance proposed by Cammidge and Howard. The amount of variation within the two lines,

Table 2. Summary of isolated tissue data (mean $\pm S D$ ) from adult male $F_{\mathbf{3}} H G$-and $L G$-line mice ${ }^{1}$

\begin{tabular}{|c|c|c|}
\hline Parameter measured & $\mathrm{HG}$ line & LG line \\
\hline \multicolumn{3}{|l|}{$\begin{array}{l}\text { 1. Hemidiaphragm response to } \\
\text { mouse insulin }^{2}\end{array}$} \\
\hline Control & \pm 33.2 & \pm 30.0 \\
\hline Insulin, $500 \mu \mathrm{U} / \mathrm{ml}$ & \pm 17.4 & \pm 28.6 \\
\hline \multicolumn{3}{|l|}{$\begin{array}{l}\text { 2. Epididymal fat pad dose response } \\
\text { to mouse insulin }\end{array}$} \\
\hline $13 \mathrm{uU} / \mathrm{ml}$ & $7.06 \pm 1.88$ & $4.14+1.24$ \\
\hline $63 \mu \mathrm{U} / \mathrm{ml}$ & $8.15 \pm 1.45$ & $6.38 \pm 1.23$ \\
\hline $190 \mathrm{uU} / \mathrm{ml}$ & $26.21 \pm 4.00$ & $23.07 \pm 1.96$ \\
\hline $508 \mu \mathrm{U} / \mathrm{ml}$ & $25.66 \pm 4.05$ & $22.65 \pm 2.70$ \\
\hline \multicolumn{3}{|l|}{ 3. Retinal metabolism of glucose ${ }^{4}$} \\
\hline${ }^{14} \mathrm{CO}_{2}$ from Glucose $-1.14 \mathrm{C}(\mathrm{n}=4)$ & $0.077 \pm 0.032$ & $0.076 \pm 0.025$ \\
\hline${ }^{14} \mathrm{CO}_{2}$ from Glucose-6- ${ }^{14} \mathrm{C}(\mathrm{n}=4)$ & $0.100 \pm 0.043$ & $0.071 \pm 0.039$ \\
\hline Glucose uptake $(n=8)$ & $0.546 \pm 0.138$ & $0.580 \pm 0.131$ \\
\hline 4. Liver glycogen content ${ }^{5}$ & $1.52 \pm 0.63$ & $1.76 \pm 1.07$ \\
\hline 5. Hepatic gluconeogenesis ${ }^{6}$ & $87.13 \pm 37.6$ & $57.90 \pm 28.7$ \\
\hline 6. Pancreatic insulin content ${ }^{7}$ & 2.3 & 2.4 \\
\hline \multicolumn{3}{|l|}{ 7. Serum insulin-like activity (ILA) ${ }^{8}$} \\
\hline Suppressible ILA & 30 & 38 \\
\hline Nonsuppressible ILA & 54 & 43 \\
\hline Total ILA & 84 & 81 \\
\hline
\end{tabular}

1 Mice were matched for age and body weight; $\mathbf{n}=8$ for each line except where indicated. For significance levels see text.

2 Data recorded as $\mu$ moles uptake/g dry wt/h.

3 Data recorded as $\mathrm{m} \mu$ moles ${ }^{14} \mathrm{CO}_{2} / g$ wet $\mathrm{wt} / \mathrm{h}$.

4 Values expressed as $\mu$ moles ${ }^{14} \mathrm{CO}_{2}$ per $\mathrm{mg} / \mathrm{h}$, and as $\mu$ moles glucose uptake/ $\mathrm{mg} / \mathrm{h}$.

5 Percent dry weight at time of sacrifice.

6 Data recorded as $\mu$ moles glucose produced/g/h from lactic acid substrate.

7 Units/g pancreas (pooled pancreata).

8 Results of bioassay of pooled serum diluted $(1: 5) \mu \mathrm{U} / \mathrm{ml}$.

\section{Discussion}

\section{Genetic Selection}

Early-studies by Cammidge and Howard $[4,5]$ concluded that FBG levels in mice were determined by combinations of three alleles at a single autosomal locus. Hyperglycemia and hypoglycemia were both recessive to normoglycemia and hypoglycemia was reported to be recessive to hyperglycemia. More recently, Charleworth [17] studied the inheritance of blood glucose levels in five strains of mice including the Swiss mouse being utilized in this investigation. After making crosses between the strains and subjecting the data to analysis of variance, she concluded that, although the differences between the strains were small, they were inherited. No mention was made, however, as to whether the blood glucose measurements were made in the fasted or randomfed state. on the other hand, indicates that FBG levels in mice are probably also influenced by other genetic and/or physiologic factors.

Body weight which were quite similar in the $P_{1}$ generation of the $\mathrm{HG}$ and LG lines, differed by 2 to $3 \mathrm{~g}$ in the $\mathrm{F}_{2}$, and from 7 to $10 \mathrm{~g}$ in the $\mathrm{F}_{4}$ generation; the HG line animals becoming heavier than LG line animals of the same age. The reason for this change is not known.

\section{Glucose Tolerance Test}

In general, glucose tolerance tests performed in $\mathrm{HG}$ and $L G$ line mice resulted in nearly parallel curves (Fig. 1), HG line animals showing the poorer glucose tolerance.

Glucose tolerance results in $\mathrm{HG}$ and $\mathrm{LG}$ line mice fed different diets indicated a definite dietary influence on this response. It appeared that line differences 
persisted when both $\mathrm{HG}$ and $\mathrm{LG}$ mice were fed the same diet (Fig. 2a). LG line mice performed differently when animals on different diets were compared (Fig. 2 b), but differences between the lines were not apparent when HG line mice received the low fat diet and LG mice received the high fat diet (Fig. $2 \mathrm{c}$ ).

A series of studies by Cole et al. describe two strains of rats differing in glucose tolerance which show striking similarities to $\mathrm{HG}$ and LG line mice such as nearly parallel glucose tolerance test curves differing by about $30 \mathrm{mg} \%$ at each point, and a more rapid growth rate in the strain with higher glucose levels [18]. The authors concluded that decreased glucose tolerance is probably the result of one principal gene plus modifiers with the principal gene tending to be incompletely recessive [19].

\section{Isolated Tissue Studies}

The results of several HG and LG line comparisons with respect to isolated tissues revealed no statistically significant differences. In general, however, the importance of these early results in $\mathbf{F}_{3}$ animals must await further analysis of subsequent generations, but they presently suggest the possibility that enhanced glucose oxidation oceurs in HG tissues.

It is generally thought that insulin occupies the central role in regulation of glucose homeostasis and modulation of hepatic gluconeogenesis and glucose disposition. It is therefore somewhat suprising that no differences were found in basal IRI or basal ILA. The agreement between IRI values and suppressible ILA, however, suggests that most of the circulating immunoreactive insulin is biologically active, at least on isolated adipose tissue. In contrast, the failure to identify a significant line difference in serum nonsuppressible ILA is not surprising since few studies have demonstrated a physiological role for this activity in glucose homeostasis.

Acknowledgements. The authors gratefully acknowledge the technical assistance of the following: Mr. Arvids Klavins, Mrs. Marta Grinbergs, Mrs. Daisy Shen, Mrs. Maija Grinbush, and Mr. Alex Cirulis.

\section{References}

1. Brook lodge workshop on spontaneous diabetes in laboratory animals. Diabetologia 3, 63-286 (1967).

2. Gleason, R.E., Lauris, V., Soeldner, J.S.: Studies on experimental diabetes in the Wellesley hybrid mouse III. Dietary effects and similar changes in a commercial Swiss-Hauschka strain. Diabetologia 3, 175$178(1967)$.
3. Kramer, M.W., Liberman, D.F., Soeldner, J.S., Gleason, R.E.: Dissociation of hyperglycemia and obesity in mice fed high fat diets. Diabetologia 5, $353-355$ (1969).

4. Cammidge, P.J., Howard, H.A.H.: Hyperglycemia as a mendelian recessive character in mice. J. Genet. 16, 387-392 (1926).

5. Cammidge, P.J., Howard, H.A.H.: The hereditary transmission of hypoglycemia in mice. Proc. roy. Soc. Med. 23, 1341-1343 (1930).

6. Dunn, L.C., Fisher, R.A. : A new series of allelomorphs in mice. Nature (Lond.) 129, 130 (1932).

7. Gruneberg, H. Haldane, J.B.S.: Congenital hyperglycemia in mice. Nature (Lond,) 145, 704-705 (1940).

8. Soeldner, J.S., Slone, D.: Critical variables in the radioimmunoassay of serum insulin using the double antibody technic. Diabetes 14, 771-779 (1965).

9. Davoren, P.R.: The isolation of insulin from a single cat pancreas. Biochem. biophys. Acta 63, 150-153 (1962).

10. Chick, W.L., Lavine, R.L., Like, A.A.: Studies in the diabetic mutant mouse: $V$. Glucose tolerance in mice homozygous and heterozygous for the diabetes ( $\mathrm{db}$ ) gene. Diabetologia 16, 257-262 (1970).

11. Renold, A.E., Martin, D. B., Dagenais, Y.M., Steinke, J., Nickerson, R.J., Sheps, M.C.: Measurement of small quantities of insulin-like activity using rat adipose tissue. I. A proposed procedure. J. clin. Invest. 39, $1487-1497(1960)$.

12. Ensinck, J.W., Poffenbarger, P.L., Hogan, R.A., Williams, R.H.: Studies of insulin antagonism. I. An artificial antagonist to insulin and plasma nonsuppressible insulin-like activity occurring in preparation of "albumin". Diabetes 16, 289-301 (1967).

13. Krebs, H.A., Notton, B.M., Hems, R.: Gluconeogenesis in mouse liver slices. Biochem. J. 101, 607-617 (1966).

14. Van Handel, E.: Estimation of glycogen in small amounts of tissue. Anal. Biochem. 11, 256-265 (1965).

15. Lowry, O.H., Rosebrough, N.J., Farr, A.L., Randell, R.J.: Protein measurement with the Folin phonol reagent. J. biol. Chem. 193, 265-275 (1951).

16. Steel, R.G.D., Torrie, J.H.: Principles and procedures of statistics, p. 73 and 183. New York: Mc Graw-Hill 1960.

17. Charlesworth, D.: Small, inherited differences in blood glucose levels in mice. Genet. Res. 14, $1-7$ (1969).

18. Cole, V.V., Harned, B.K. : Diabetic traits in a strain of rats. Endocrinology 23, 318-326 (1938).

19. Cole, V.V., Harned, B.K., Keeler, C.E.: Inheritance of glucose tolerance. Endocrinology 28, 25-32 (1941).

Ray E. Gleason, Ph.D.

Senior Investigator

Elliott P. Joslin Research Laboratory

170 Pilgrim Road

Boston, Mass. 02215

USA 